\title{
Effect of storage on physicochemical characteristics of instant foam mat dried mango fruit powder and its utilization for the preparation of ready to serve (RTS) beverage
}

\author{
Anil Kumar Verma ${ }^{\star}$, Namita Rani, Raj Saini*, Preeti Choudhary, Hamid and Shivani \\ Department of Food Science and Technology, College of Horticulture and Forestry, Neri, Hamirpur-177001, Himachal Pradesh, India \\ *Department of Basic Sciences, College of Horticulture and Forestry, Neri, Hamirpur-177001, Himachal Pradesh, India
}

\section{Article Info}

Article history

Received 20 August 2021

Revised 6 October 2021

Accepted 7 October 2021

Published Online 30 December 2021

\section{Keywords}

Mango fruit cultivars

Instant powder

Carboxy methyl cellulose

Storage evaluation

\begin{abstract}
The mango pulp of three cultivars, viz., Amrapali, Dashehari, Mallika and one Seedling mango was converted into mango powder in dehydrator $\left(60 \pm 5^{\circ} \mathrm{C}\right)$ to a constant moisture level using whipping of pulp for 5 min after addition of carboxy methyl cellulose (CMC) @ 2\%. Further, the prepared powder was analyzed for various physicochemical characteristics. The fruit powder prepared with $2 \%$ CMC of all cultivars packed in aluminum laminated pouches, stored at ambient temperature was evaluated at $0,30,60$ and 90 days intervals to study the storage stability. Slight increase was reported in $\mathrm{pH}$ moisture content and reducing sugar during storage period of 90 days at ambient temperature $\left(30-35^{\circ} \mathrm{C}\right)$. On the other hand, TSS, titratable acidity and total carotenoids decreased during the storage period up to 90 days. No apparent growth of moulds, yeasts and bacteria was detected in all the instant mango powders during storage at ambient temperature, which showed that the prepared instant mango powders were safe for consumption during a period of three month of storage. It was concluded that mango pulp of all the cultivars, Amrapali, Dashehari and Mallika including Seedling mango can successfully be used for preparation of foam mat dried powder and further can be utilized for the preparation of drink.
\end{abstract}

\section{Introduction}

Mango (Mangifera indica L.) is one of our country's most significant indigenous tropical fruits, with a broad range of adaptation due to its high nutritional content, delicious taste, outstanding flavor and appealing look. Its fruits are good source of various macronutrients (carbohydrates, lipids and fatty acids, protein and amino acids besides organic acids) and other micronutrients (vitamins and minerals) in addition, to various phytochemicals (polyphenolic compounds, flavonoids, chlorophyll, carotenoids and volatile chemicals) (Maldonado-Celis et al., 2019; Rani et al., 2020; Thakur et al., 2017). Different cultivars of mango (Amrapali, Dashehari, Mallika and Seedling mango) contain variable amount of total soluble solids $\left(13.26-16.05^{\circ} \mathrm{B}\right)$, titratable acidity $(0.14-0.31 \%), \mathrm{pH}(3.82-$ $4.44)$, ascorbic acid $(16.58-30.12 \mathrm{mg} / 100 \mathrm{ml})$, total carotenoids $(1.57-2.91 \mathrm{mg} / 100 \mathrm{ml})$, reducing sugar $(5.06-6.14 \%)$ and total sugar $(12.42-15.03 \%$ ) (Rani et al., 2020). Due to its higher production and nutritional value, it is converted into various processed forms after and before ripening (Thakur et al., 2019; Rani et al., 2020). But, mango is a seasonal fruit, thus around only $20 \%$ of them are processed into pure, beverages (nectar), pickles, leather, chutney and canned slices (Ravani and Joshi, 2013). This might be due to high perishability and susceptibility to mechanical damage during post-harvest handling, as well as poor transportation and storage facilities, which leads to large gap between total production and consumption. Fruit processing reduces these losses to some extent

\section{Corresponding author: Dr. Anil Kumar Verma}

Assistant Professor, Department of Food Science and Technology, College of Horticulture and Forestry, Neri, Hamirpur-177001, Himachal Pradesh, India

E-mail: anivverma@gmail.com

Tel.: +91-9816317327

Copyright (C) 2021 Ukaaz Publications. All rights reserved.

Email: ukaaz@yahoo.com; Website: www.ukaazpublications.com and provides growers with greater yields during surplus seasons. As a result, converting ripe mango fruits into processed commodities like instant mango powder may be beneficial not only in reducing post-harvest losses but also in preserving nutritional content in the processed products. Among various drying methods, foam mat drying is one of the alternate techniques to convert mango pulp into instant powder using carboxy methyl cellulose which reconstitutes rapidly to a quality products, resembling the original juice (Rani et al., 2020). Aside from different cultivars, Seedling mango fruits are abundant, particularly in Himachal Pradesh's low foothills, however, a substantial proportion of these fruits are wasted during harvesting season. Thus, the present study was performed with the objective to convert mango pulp of Amrapali, Dashehari, Mallika cultivars with available pulp of Seedling mango into instant mango powder, using foam mat drying with a minimum cost and its shelf-life evaluation during storage at ambient temperature. Further, the instant powder was utilized for the preparation of drink and its comparative sensory acceptability was evaluated.

\section{Materials and Methods}

2.1 Raw material and preparation of instant mango powder

The present study was undertaken in the Department of Food Science and Technology, College of Horticulture and Forestry, Dr. YS Parmar University of Horticulture and Forestry, Neri, Hamirpur, HP during the year 2017-2019. Mango fruits of three cultivars, viz., Amrapali, Dashehari, Mallika and Seedling mango procured from Regional Horticulture and Forestry Research and Training Centre, Bhota, Hamirpur (HP), and surroundings areas especially of Seedling mango were utilized for this study. Afterward, the fruits 
were used for extraction of pulp by following Rani et al. (2020) method, in which pulp was extracted by fruit pulper followed by heating at $90^{\circ} \mathrm{C}$ and preservation with potassium metabisulphite (2 $\mathrm{g} / \mathrm{kg}$ of pulp) in sterilized glass bottles for later utilization. The mango pulp of three cultivars, viz., Amrapali, Dashehari, Mallika and one Seedling mango was converted into mango powder in dehydrator $\left(60 \pm 5^{\circ} \mathrm{C}\right)$ to a constant moisture level for about 4-8 $\mathrm{h}$ using whipping of pulp for 5 min after addition of carboxy methyl cellulose (CMC) @ 2\% (Rani et al., 2020). The pulp being thin and juicy was converted into stable foam by CMC @ $2 \%$, followed by spreading the foam on stainless steel trays $\left(30 \times 20 \mathrm{~cm}^{2}\right.$, with a tray load of $150 \mathrm{~g}$ per tray) in a thin layer $(3-5 \mathrm{~mm})$ and dried in a mechanical dehydrator $\left(60 \pm 5^{\circ} \mathrm{C}\right)$. The dried foam was scrapped from the trays and ground to a fine powder, followed by packing in aluminum pouches.

\subsection{Packaging and storage of instant mango powder}

The storage stability of foam mat dried mango powder kept at ambient temperature $\left(30-35^{\circ} \mathrm{C}\right)$ was evaluated after packing in aluminium pouches at different storage intervals of $0,30,60$ and 90 days for various physicochemical and sensory characteristics. Further, mango powder was evaluated for preparation of ready-toserve beverage. The suitability of utilizing mango pulp powder kept at different storage intervals $(0,30,60,90$ days) for the preparation of ready-to-serve beverage of acceptable sensory qualities was evaluated. The beverage was prepared by using $15 \%$ of fruit powder of each variety at fixed total soluble solids of $12^{\circ} \mathrm{B}$ raised by using cane sugar syrup.

\subsection{Chemical analysis}

Moisture, TSS (total soluble solids), sugars, titratable acidity and ascorbic acid content of samples were determined according to the standard procedures (Ranganna, 2014). The $\mathrm{pH}$ of the prepared powder (after dilution) was determined with the help of automatic pH meter (Deluxe pH meter model 101).

\subsection{Sensory evaluation and statistical analysis}

The sensory evaluation of foam mat dried mango powder was conducted using the nine-point hedonic scale method proposed by Amerine et al. (1965). The chemical properties of instant powder were analyzed statistically using Cochran and Cox's (1967) Completely Randomized Design (CRD).

\section{Results}

\subsection{Storage of instant mango powder}

Out of different combinations as performed in previous study (Rani et al., 2020), use of $2 \%$ carboxy methyl cellulose in each variety was found the most appropriate for foaming of mango pulps and highly acceptable on the basis of foaming properties and sensory quality. Therefore, mango powders prepared by using $2 \%$ carboxy methyl cellulose were packed in aluminium pouches and stored at ambient temperature $\left(30-35^{\circ} \mathrm{C}\right)$ and evaluated at storage intervals of $0,30,60$ and 90 days to evaluate the storage stability. The results are discussed as under:

\subsubsection{Moisture content (\%)}

Data presented in Table 1 showed that among different storage intervals, the mean moisture content was recorded maximum (6.92 $\%$ ) in mango powder of different cultivars after 90 days of storage and minimum $(5.59 \%)$ at zero day storage. It was observed that moisture content increased with an increase in storage intervals $(0$ to 90 days). Among different cultivars, the mean moisture content was recorded maximum in cv. Mallika powder (6.54\%), followed by cv. Dashehari $(6.25 \%)$ and minimum in cv. Amrapali powder $(6.09 \%)$. The interaction between cultivars and storage intervals were found to be significant. The maximum moisture content $(7.25$ $\%$ ) was observed in cv. Mallika powder after 90 days of storage and minimum in cv. Amrapali powder $(5.50 \%)$ at zero day of storage.

\subsubsection{Total soluble solids $\left({ }^{\circ} \mathrm{B}\right)$}

Data presented in Table 2 indicate that the mean total soluble solids (TSS) were recorded maximum $\left(82.28^{\circ} \mathrm{B}\right)$ in mango powder of all cultivars at zero day storage and minimum $\left(80.55^{\circ} \mathrm{B}\right)$ after 90 days of storage. The TSS of mango powder was observed to decrease significantly with the advancement of storage intervals. Among different mango cultivars, the mean total soluble solids were recorded maximum in cv. Amrapali powder $\left(82.70^{\circ} \mathrm{B}\right)$, followed by $81.33^{\circ} \mathrm{B}$ in Dashehari powder and minimum $79.90^{\circ} \mathrm{B}$ in Seedling mango powder. The interaction between cultivars and storage intervals were found to be significant for TSS. The maximum TSS $\left(83.70^{\circ} \mathrm{B}\right)$ was recorded in cv. Amrapali powder at zero day storage and minimum in Seedling mango powder $\left(79.10^{\circ} \mathrm{B}\right)$ after 90 days storage.

Table 1: Effect of storage intervals on the moisture content (\%) of the mango powder of different cultivars

\begin{tabular}{|c|c|c|c|c|c|}
\hline \multirow[t]{2}{*}{ Cultivars } & \multicolumn{4}{|c|}{ Storage intervals (Days) } & \multirow[t]{2}{*}{ Mean (C) } \\
\hline & 0 & 30 & 60 & 90 & \\
\hline Amrapali & 5.50 & 5.94 & 6.30 & 6.62 & 6.09 \\
\hline Dashehari & 5.55 & 6.00 & 6.53 & 6.92 & 6.25 \\
\hline Mallika & 5.72 & 6.25 & 6.94 & 7.25 & 6.54 \\
\hline Seedling mango & 5.51 & 5.98 & 6.50 & 6.90 & 6.22 \\
\hline Mean (S) & 5.59 & 6.04 & 6.56 & 6.92 & \\
\hline \multicolumn{6}{|l|}{ CD0.05 } \\
\hline
\end{tabular}


Table 2: Effect of storage intervals on the total soluble solids $\left({ }^{\circ} \mathbf{B}\right)$ of the mango powder of different cultivars

\begin{tabular}{|c|c|c|c|c|c|}
\hline \multirow[t]{2}{*}{ Cultivars } & \multicolumn{4}{|c|}{ Storage intervals Days } & \multirow[t]{2}{*}{ Mean (C) } \\
\hline & 0 & 30 & 60 & 90 & \\
\hline Amrapali & 83.70 & 82.90 & 82.30 & 81.90 & 82.70 \\
\hline Dashehari & 82.00 & 81.36 & 81.20 & 80.76 & 81.33 \\
\hline Mallika & 82.40 & 81.53 & 81.30 & 80.46 & 81.42 \\
\hline Seedling mango & 81.05 & 79.86 & 79.60 & 79.10 & 79.90 \\
\hline Mean (S) & 82.28 & 81.41 & 81.10 & 80.55 & \\
\hline \multicolumn{6}{|l|}{ CD0.05 } \\
\hline
\end{tabular}

Table 3: Effect of storage intervals on the reducing sugar (\%) of the mango powder of different cultivars

\begin{tabular}{|c|c|c|c|c|c|}
\hline \multirow[t]{2}{*}{ Cultivars } & \multicolumn{4}{|c|}{ Storage intervals (Days) } & \multirow[t]{2}{*}{ Mean (C) } \\
\hline & 0 & 30 & 60 & 90 & \\
\hline Amrapali & 48.62 & 49.31 & 49.45 & 49.55 & 49.24 \\
\hline Dashehari & 43.14 & 43.28 & 43.39 & 43.55 & 43.34 \\
\hline Mallika & 46.69 & 46.75 & 46.85 & 46.98 & 46.81 \\
\hline Seedling mango & 42.62 & 42.87 & 43.07 & 43.34 & 42.97 \\
\hline Mean (S) & 45.26 & 45.55 & 45.69 & 45.85 & \\
\hline
\end{tabular}

Table 4: Effect of storage intervals on the total sugar (\%) of the mango powders of different cultivars

\begin{tabular}{|c|c|c|c|c|c|}
\hline \multirow[t]{2}{*}{ Cultivars } & \multicolumn{4}{|c|}{ Storage intervals (Days) } & \multirow[t]{2}{*}{ Mean (C) } \\
\hline & 0 & 30 & 60 & 90 & \\
\hline Amrapali & 80.05 & 79.92 & 79.80 & 79.43 & 79.80 \\
\hline Dashehari & 79.50 & 79.35 & 79.19 & 79.05 & 79.27 \\
\hline Mallika & 79.90 & 79.77 & 79.60 & 79.32 & 79.40 \\
\hline Seedling mango & 77.75 & 77.60 & 77.49 & 77.35 & 77.55 \\
\hline Mean (S) & 79.30 & 79.16 & 78.77 & 78.78 & \\
\hline \multicolumn{6}{|l|}{ CD0.05 } \\
\hline \multicolumn{6}{|c|}{ Cultivars $(C)=0.365$, Storage intervals $(S)=0.365, C \times S=N S$} \\
\hline
\end{tabular}

\subsubsection{Reducing sugar $(\%)$}

Data presented in Table 3 indicate that the mean reducing sugar was recorded maximum $(45.85 \%)$ after 90 days of storage and minimum $(45.26 \%)$ at zero day storage. It was observed that reducing sugar increased with an increase in storage intervals. Among different cultivars of mango fruit, the mean reducing sugar was recorded maximum in cv. Amrapali powder (49.24\%), followed by cv. Mallika $(46.81 \%)$ and minimum in Seedling mango powder $(42.97 \%)$. The interaction between cultivars and storage intervals were found to be significant. The maximum reducing sugar $(49.55 \%)$ was observed in cv. Amrapali powder after 90 days of storage and minimum in Seedling mango powder (42.62\%) at zero day of storage.

\subsubsection{Total sugars $(\%)$}

Scrutiny of data in Table 4 show that the mean total sugar was recorded maximum $(79.30 \%)$ at zero days of storage and minimum $(78.78 \%)$ after 90 days storage in mango powder of different cultivars.

It was observed that total sugar decreased with an increase in storage intervals. Among different cultivars of mango fruit, the mean total sugar was recorded maximum in cv. Amrapali powder (76.80\%), followed by cv. Mallika (79.40 \%) and minimum recorded in Seedling mango powder $(77.55 \%)$. The interaction between cultivars and storage intervals were found to be significant. The maximum total sugar was observed $80.05 \%$ in cv. Amrapali powder at zero day of storage and minimum in Seedling mango powder $77.35 \%$ after 90 days of storage. 


\subsubsection{Titratable acidity $(\%)$}

A perusal of data in Figure 1 shows that the mean titratable acidity was recorded maximum $(1.04 \%)$ in zero day storage and minimum $(0.92 \%)$ after 90 days of storage in mango powder of all cultivars, which shows a decreasing trend with increase in storage intervals. Among different cultivars of mango fruit, the mean titratable acidity was recorded maximum in Seedling mango powder $(1.18 \%)$, followed by cv. Dashehari (0.98 \%) and minimum in cv. Mallika powder $(0.87 \%)$. Among different cultivars and storage intervals, the maximum titratable acidity $(1.23 \%)$ was observed in Seedling mango powder at zero day storage and minimum in cv. Amrapali powder $(0.81 \%)$ after 90 days storage. The interaction between cultivars and storage intervals were found to be non-significant.

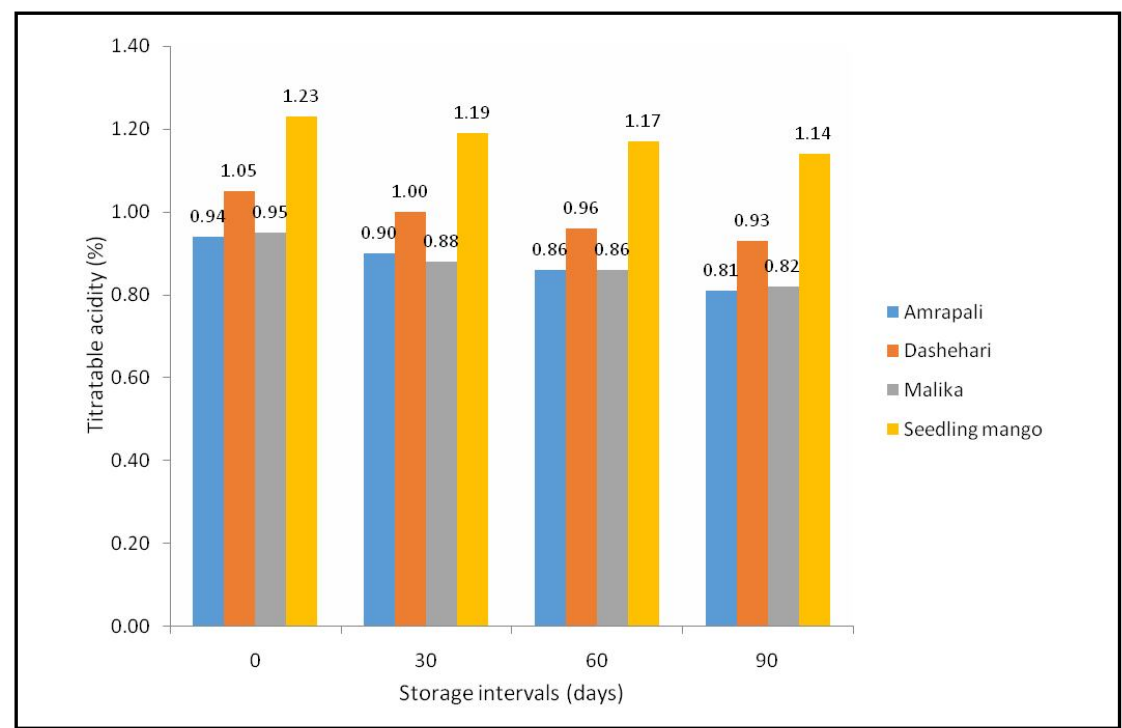

Figure 1: Effect of storage intervals on the titratable acidity (\%) of the mango powder of different cultivars.

Table 5: Effect of storage intervals on the $\mathrm{pH}$ of the mango powder of different cultivars

\begin{tabular}{|l|c|c|c|c|c|}
\hline \multirow{2}{*}{ Cultivars } & \multicolumn{4}{|c|}{ Storage intervals (Days) } & Mean (C) \\
\cline { 2 - 6 } & 0 & 30 & 60 & 90 & 4.81 \\
\hline Amrapali & 4.75 & 4.79 & 4.84 & 4.80 & 4.74 \\
\hline Dashehari & 4.70 & 4.73 & 4.76 & 4.90 & 4.84 \\
\hline Mallika & 4.79 & 4.82 & 4.86 & 4.23 & 4.17 \\
\hline Seedling mango & 4.10 & 4.15 & 4.19 & 4.70 & \\
\hline Mean (S) & 4.58 & 4.62 & 4.66 & & \\
\hline CD0.05 \\
Cultivars (C) $=0.012$, Storage intervals $(\mathrm{S})=0.012, \mathrm{C} \times \mathrm{S}=\mathrm{NS}$
\end{tabular}

Table 6: Effect of storage intervals on the total carotenoids (mg/100 $\mathrm{g}$ ) of the mango powder of different cultivars

\begin{tabular}{|c|c|c|c|c|c|}
\hline \multirow[t]{2}{*}{ Cultivars } & \multicolumn{4}{|c|}{ Storage intervals (Days) } & \multirow[t]{2}{*}{ Mean (C) } \\
\hline & 0 & 30 & 60 & 90 & \\
\hline Amrapali & 11.94 & 11.84 & 11.66 & 11.52 & 11.74 \\
\hline Dashehari & 11.84 & 11.70 & 11.46 & 11.30 & 11.57 \\
\hline Mallika & 11.96 & 11.87 & 11.72 & 11.58 & 11.78 \\
\hline Seedling mango & 11.77 & 11.67 & 11.37 & 11.24 & 11.51 \\
\hline Mean (S) & 11.88 & 11.77 & 11.55 & 11.41 & \\
\hline \multicolumn{6}{|l|}{ CD0.05 } \\
\hline
\end{tabular}


Table 7: Sensory evaluation of ready-to-serve beverage made from mango powders of different cultivars

\begin{tabular}{|l|c|c|c|c|}
\hline Cultivars & Color & Taste & Aroma & $\begin{array}{c}\text { Overall } \\
\text { acceptability }\end{array}$ \\
\hline Amrapali & $8.50 \pm 0.012$ & $8.93 \pm 0.017$ & $8.90 \pm 0.058$ & $8.94 \pm 0.021$ \\
\hline Dashehari & $8.40 \pm 0.006$ & $8.60 \pm 0.058$ & $8.50 \pm 0.032$ & $8.54 \pm 0.024$ \\
\hline Mallika & $8.40 \pm 0.012$ & $8.80 \pm 0.058$ & $8.80 \pm 0.011$ & $8.80 \pm 0.032$ \\
\hline Seedling mango & $7.50 \pm 0.006$ & $8.00 \pm 0.058$ & $7.90 \pm 0.014$ & $7.96 \pm 0.010$ \\
\hline
\end{tabular}

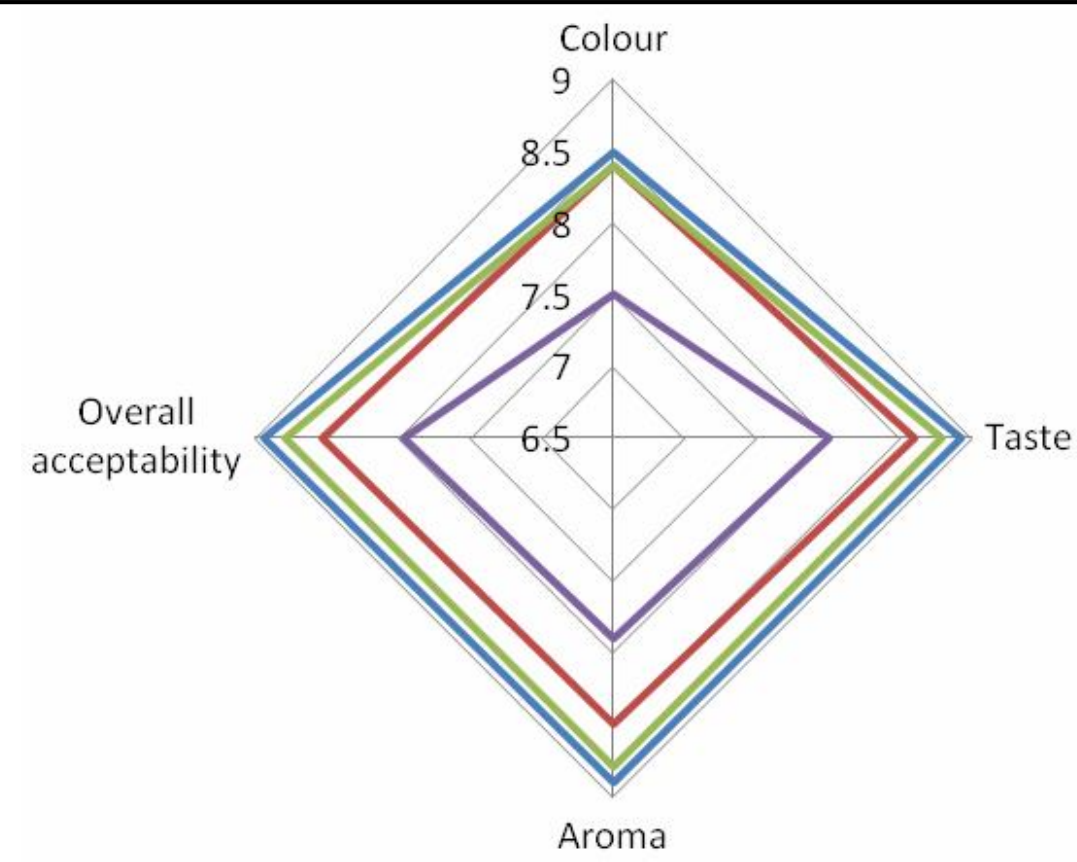

- Amrapali

Dashehari

- Mallika

Seedling mango

Figure 2: Sensory characteristics (9-point hedonic scale) of RTS beverage prepared from different cultivars of mango.

\subsection{6 pH}

A perusal of data in Table 5 indicates that among different storage intervals, the mean $\mathrm{pH}$ was recorded maximum (4.70) after 90 days of storage and minimum (4.58) at zero day of storage in all mango powder of different cultivars. The $\mathrm{pH}$ of mango powders was observed to increase with an increase in storage intervals. Among different cultivars of mango fruit, the mean $\mathrm{pH}$ was recorded maximum in cv. Mallika powder (4.84) and minimum in Seedling mango powder (4.17). Among different cultivars and storage intervals, the maximum $\mathrm{pH}$ (4.90) was observed in cv. Mallika powder after 90 days of storage and minimum in Seedling mango powder (4.10) at zero day of storage. However, interaction between cultivars and storage intervals was found to be non-significant.

\subsubsection{Total carotenoids $(\mathrm{mg} / \mathbf{1 0 0} \mathrm{g})$}

A perusal of data in Table 6 indicates that the mean total carotenoids were recorded maximum $(11.88 \mathrm{mg} / 100 \mathrm{~g})$ at zero day of storage and minimum $(11.41 \mathrm{mg} / 100 \mathrm{~g})$ after 90 days of storage in mango powder of different cultivars. It was observed that total carotenoids were decreased with an increase in storage intervals. Among different cultivars of mango fruit, the mean total carotenoids was recorded maximum in cv. Mallika powder $(11.78 \mathrm{mg} / 100 \mathrm{~g})$ while minimum was recorded in Seedling mango powder $(11.51 \mathrm{mg} / 100 \mathrm{~g})$. The maximum total carotenoids $(11.96 \mathrm{mg} / 100 \mathrm{~g})$ was observed in $\mathrm{cv}$. Mallika powder at zero day of storage and minimum total carotenoids in Seedling mango powder $(11.24 \mathrm{mg} / 100 \mathrm{~g})$ after 90 days of storage.

3.2 Sensory quality of RTS beverages prepared from mango powder of different cultivars

The data pertaining to the sensory quality of the RTS beverages prepared from mango powder of different cultivars presented in Table 7 (Figure 1) reveal that RTS beverage prepared by using cv. Amrapali powder was found best on the basis of sensory quality as compared to RTS prepared from other cultivars.

The data recorded for colour mean score remained highly significant within all different cultivars of mango ranging from 7.50 to 8.50 (Table 7). Colour score was recorded highest (8.50) for cv. Amrapali and lowest (7.50) for Seedling mangoes. The data presented in Table 8 that the taste score of the RTS beverages ranging from 8.00 to 8.93 with 9 -point hedonic scale. However, taste score was recorded higher (8.93) of RTS prepared from cv. Amrapali powder and lowest (8.00) for RTS prepared from Seedling mango powder. 
Data presented in Table 7 (Figure 2) showed that the aroma score of the RTS beverages ranging from 7.90 to 8.90 with 9-point hedonic scale. However, aroma score was recorded higher (8.90) of RTS prepared from cv. Amrapali powder and lowest (7.90) for RTS prepared from Seedling mango powder. A perusal of data in Table 8 that the overall acceptability of the RTS beverages ranging from 7.96 to 8.94 with 9-point hedonic scale. However, overall acceptability was recorded higher (8.94) of RTS prepared from cv. Amrapali powder and lowest (7.96) for RTS prepared from Seedling mango powder.

Cost of production for preparation of mango powder after adding $20 \%$ profit margin was found to be Rs. $72.42 / 100 \mathrm{~g}$ for cv. Amrapali powder, Rs. 61.61/100 g for cv. Dashehari powder, Rs. 78.01/100 $\mathrm{g}$ for cv. Mallika powder and Rs. 48.12/100 g for Seedling mango powder.

\section{Discussion}

Slight increase in moisture content was observed in various mango powders during storage. These changes can be attributed to the environmental changes, which will bring changes in the relative humidity outside the packaging system, resulting permeation of moisture content and absorption due to high hydrostatic nature of powder. Gradual increase in moisture content with increase in storage intervals has been recorded in banana powder by Barooah et al. (2018), in hill lemon juice powder (4.86-11.37 per cent) by Sharma et al. (2004) and in ber powder by Rodge and Yadlod (2009). Significant decrease in values of TSS was observed in various instant mango powders packed in aluminum laminated pouches during storage which might be due the degradation of various components of total soluble solids. Higher total soluble values were observed in powder prepared from Amrapali variety of mango and lowest TSS was observed in powder prepared from seedling mango. These changes were gradually lower in instant mango powder of Dashehari cultivar, compared to that of other treatments. These results are in confirmation with the results obtained by Sivakumar and Malathi (2016) who have also recorded decrease in TSS $\left(38.85-38.50^{\circ} \mathrm{B}\right)$ of foam mat dried mango powder based ice cream. Similar decrease in TSS content in papaya powder was also recorded by Shivani $e t$ al. (2020). Slight increase in reducing sugar content was observed in various mango powders during storage. This increase in reducing sugars during storage intervals is attributed due to polysaccharides hydrolysis into monosaccharide and disaccharides. Similar trend of increase in reducing sugars during storage was recorded in banana powder (24.98-28.40 g) by Barooah et al. (2018) and in hill lemon juice powder (17.10-17.42 per cent) by Sharma et al. (2004). Slight decreasing trend in reducing sugar content was observed in various mango powders during storage. The decrease in total sugars during storage intervals is attributed due to their involvement in nonenzymatic reactions. Whereas, minimum decreased of total sugars were found in seedling mango powder. Similar trend of reduction in total sugars was recorded in foam mat dried hill lemon juice powder (45.82-45.53 per cent) by Sharma et al. (2004). Titratable acidity of various instant mango powders were decreased during storage of 90 days under aluminium laminated packaging due to involvement of various organic acids in browning reactions under ambient temperature. Similar trends of reduction in titratable acidity has been recorded in banana powder (3.66-2.30 per cent) by Barooah et al. (2018) and in hill lemon juice powder (43.54-42.79 per cent) by Sharma et al. (2004) during storage. However, $\mathrm{pH}$ of various instant mango powders were increased during storage of 90 days under aluminium laminated packaging. The increase in $\mathrm{pH}$ of mango powder during storage intervals attributed due to decline of titratable acidity. Similar trend in $\mathrm{pH}$ in mandarin powder has been observed by Kadam et al. (2011) and in papaya powder by Shivani et al. (2020a). Slight decreasing trend in total carotene content was observed in various mango powders during storage of 90 days. This decrease in total carotene content of various mango powders might be due to oxidation of carotene during storage of powder. Earlier, Hymavathi and Khader (2005) have reported decrease in level of total carotene $5192 \mu \mathrm{g} / 100 \mathrm{~g}$ to $2458 \mu \mathrm{g} / 100 \mathrm{~g}$ in ripe mango powders during storage.

\section{Conclusion}

On the basis of above study, it is concluded that mango pulp of all the cultivars; Amrapali, Dashehari and Mallika including Seedling mango can successfully be used for preparation of foam mat dried mango powder using $2 \% \mathrm{CMC}$ for foaming and drying the foam in mechanical dehydrator. Sensory evaluation of ready-to-serve drink prepared of different cultivars, viz., Amrapali, Dashehari, Mallika and Seedling mango fruit powder was done after 90 days of storage. Out of different cultivars ready-to-serve drink prepared from cultivar, Amrapali powder was found highly acceptable as compared to drink prepared from powder of other mango cultivars.

\section{Acknowledgements}

Authors sincerely acknowledge Dr. Yashwant Singh Parmar University College of Horticulture and Forestry, Neri, Hamirpur177001, Himachal Pradesh, India for providing entire facilities and support for conducting this research.

\section{Conflict of interest}

The authors declare no conflicts of interest relevant to this article.

\section{References}

Amerine, M.A.; Pangborn, R.M. and Rossler, E.B. (1965). Principles of sensory evaluation of food. Academic Press, New York. pp:254.

Barooah, N.; Das, P.; Barooah, M.S.; Seth, D.K. and Dutta, P. (2018). Storage studies on spray dried ripe banana powder produced by response surface methodology. International Journal of Current Microbiology and Applied Sciences, 7:1922-1933.

Cochran, W.G. and Cox, C.M. (1967). Experimental Designs. John Wiley and Sons, Inc. New York CRC Press, London, UK.

Hymavathi, T.V. and Khader, V. (2005). Carotene, ascorbic acid and sugar content of vacuum dehydrated ripe mango powders stored in flexible packaging material. Journal of Food Composition and Analysis, 18: $181-192$.

Kadam, D.M.; Rai, D.R.; Patil, R.T.; Wilson, R.A.; Kaur, S. and Kumar, R. (2011). Quality of fresh and stored foam mat dried mandarin powder. International Journal of Food Science and Technology, 46:793799 .

Mahony, M.O. (1985). Sensory evaluation of food: Statistical methods and procedures. Marcel Dekker: New York, pp:168-169.

Ranganna, S. (2014). Handbook of analysis and quality control for fruit and vegetable products. Tata McGraw Hill Co. Ltd., New Delhi. pp:1112p. 
Rani, N.; Verma, A.K.; Sharma, P.C.; Saini, R. and Shivani (2020). Composition and characterization of foam mat dried powder prepared from seedling and cultivated mango cultivars of Himalayan region. International Journal of Current Microbiology and Applied Sciences, 9(05):593-611.

Ravani, A. and Joshi, D.C. (2013). Mango and it's by product utilization: A review. Trends in Post Harvest Technology, 1(1):55-67.

Rodge, B.M. and Yadlod, S.S. (2009). Storage studies of ber powder at room temperature. Asian Sciences, 4:42-44.

Sharma, S.K.; Sharma, P.C. and Kaushal, B.B.L. (2004). Storage studies of foam mat dried hill lemon (Citrus pseudolimon Tan.) juice powder. Journal of Food Science and Technology, 41:9-13.

Shivani; Verma, A.K.; Sharma, P.C.; and Saini, R. (2020). Storage stability and utilization of foam mat dried papaya powder cv. Madhu. International Journal of Chemical Studies, 8:1220-1225.
Shivani; Verma, A.K.; Sharma, P.C.; Sharma R.C.; and Saini, R. (2020a). Formulation and acceptability of foam mat dried papaya (Carica papaya L.) powder. Journal of Pharmacognosy and Phytochemistry, 9:226-231.

Sivakumar, K.P. and Malathi, D. (2016). Development and nutritional evaluation of mango powder based instant ice cream mix in different packaging materials. International Journal of Processing and Post Harvest Technology, 7:53-59.

Thakur, N.S.; Kumar, D.; Joshi, V.K.; Thakur, A. and Hamid (2019). Cluster analysis of quality characteristics of seedling mango fruits collected from different locations of Himachal Pradesh, India for the development of pickle. International Journal of Food and Fermentation Technology, 9:117-123.

Thakur, N.S.; Kumar, D.; Thakur, A. and Hamid (2017). Studies on quality characteristics of seedling mango fruits from different locations of Himachal Pradesh. Journal of Hill Agriculture, 8:288-292.

Anil Kumar Verma, Namita Rani, Raj Saini, Preeti Choudhary, Hamid and Shivani (2021). Effect of storage on physicochemical characteristics of instant foam mat dried mango fruit powder and its utilization for the preparation of beverage. Ann. Phytomed., 10(2):130-136. http://dx.doi.org/10.21276/ap.2021.10.2.18 